\title{
The Economy in 1972
}

\author{
by ROGER W. SPENCER
}

\begin{abstract}
A 12LTHOUGH most projections of the pace of economic activity this year are quite optimistic, uncertainty continues to cloud the 1972 economic horizon. With unemployment still high by historical standards, many people remain concerned about their ability either to obtain a job to their liking or to retain their present one. Inflation and potential inflationary pressures are not yet subdued. The effectiveness of the price and wage control program is still debated by those who regard it as a necessary, long-term supplement to orthodox monetary-fiscal policies, and by those who see the program as a disturbing encroachment on individual freedom. Nineteen seventy-two could also be a year marking the most sweeping changes in the international monetary payments mechanism since the 1944 Bretton Woods Conference. Finally, all these economic developments take on added significance in light of the coming presidential election.
\end{abstract}

Many of these issues evolved over a long period and will be difficult to resolve in a single year. To assess the course of economic activity over the next several months, this article discusses first the principal influences on the course of economic activity and secondly, the economic outlook.

\section{Factors Influencing The Economic Outlook}

The chief factors to be considered in projecting the economic outlook for 1972 are given in Figure I. The three major categories are cyclical forces, structural changes and policy actions.

At any time, the economy has a certain "momentum" of its own. The direction and magnitude of the momentum reflect the particular stage of the business cycle. The momentum of cyclical forces can be offset or augmented by structural changes or stabilization policy actions.

Structural changes include developments in the world trade picture which inluence the U.S. balanceof-payments position, random events such as wars, strikes and weather shifts, as well as "other" factors. These other factors include: (1) changes in preference, stich as an increased preference for saving relative to consumption, or liquidity relative to goods and services; (2) changes in the nature or rate of increase of technological advance; (3) changes in the quantity and quality of available resources, such as a shift toward more availability of inexperienced labor resources relative to experienced labor resources; and (4) changes in the institutional and legal framework, such as the initiation of legally authorized price and wage controls in a peace-time economy.

Policy actions are the orthodtox measures employed by stabilization authorities to guide the course of economic activity. Monetary and fiscal actions taken prior to and during 1972 will have a substantial bearing on economic developments during the current year.

\section{Cyclical Infuences}

Nineteen seventy-two begins the second year of recovery from the moderate recession which ended in November 1970. Much has been made of the fact that the first year of the current recovery period was not as strong as the first year of previous recoveries, but insufficient attention has been given to the relation between the moderate recession and the moderate recovery. To the extent that forces are set in motion 


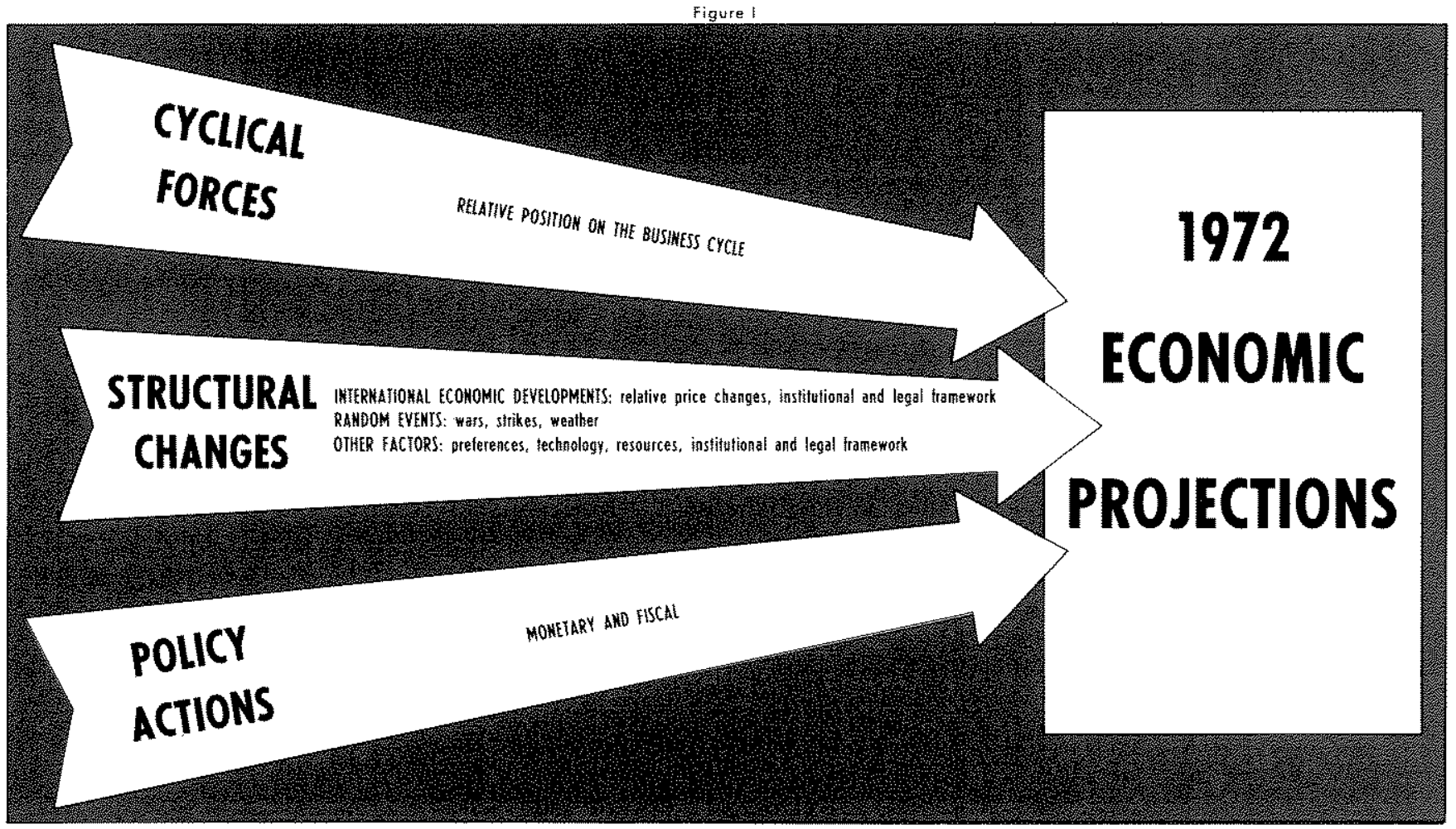

which infuence the scope of business cycles independent of policy actions or other outside forces, a strong recovery in 1971 should not have been anticipated. ${ }^{1}$ Indeed, many observers accurately predicted a moderate recovery in 1971 based, in some degree, on such reasoning.

1.Wesley C. Mitchell, a pioneer in business cycle analysis, wrote on the automatic forces inluencing the up and down phases of the cycle:

The various processes just described combine reductions in both prine costs and fixed charges with an expansion in the physical volume of business. In this fashion depression ultimately brings about revival, for of course these changes increase prospective profits, and in the money economy prospective profits are the great incentive to activity,

In fine, this business situation is that described in the first section of Chapter 1 - the situation out of which a revival of activity presently develops. Having thus cone round again to its point of departure, after tracing the processes of cumulative change by which prosperity breeds crisis, crisis evolves into depression, and depression paves the way for a return of prosperity, the present theory of business cycles has reached its appointed ent. [Wesley Clair Mitchell, Business Gyoles and Their Causes (Berkeley and Los Angeles: University of California Press, 1950), pp, 146-47. This volme is a reprint of part III of Mitchell's Business Cycles, originally ptblished in 1913 by the University of California Press.

There is some likelihood that other things equal, the more severe is the downturn due to sach factors as descrbed by Mitchell, the stronger will be the upturn. For exanple, if the downturn is of sufficient scope that even very efficient resources become memployed the efficient resources can be utilized to prodice a strong uptturn after the crisis point is passed. Outside forces, however, such as strikes and policy actions, can effectively alter this relation.
Nevertheless, the weakness of the recovery last year has contributed to the view that there has been a change in the way the economy works, that the economic principles which held in times past no longer apply. There is no question that the economy is constantly changing and the policies used to influence the course of its movement must be reasonably flexible. However, a simple comparison of the moderate recovery in 1971 with vigorous first year recoveries in the past may overstate the degree of structural change, especially with regard to production and employment.

Table I presents changes in several important economic variables for each business downswing, for each recovery and for each entire recession-early recovery period of the past two decades (see also the accompanying chart). "The "Total Period" data reflect both the depth of the recession and the strength of the early portion of the ensuing recovery. On this basis, the recent economic experience does not appear as strikingly different from other periods as a comparison of recessions alone or early recovery periods alone would suggest. ${ }^{2}$

\footnotetext{
"Most recessions are often termed "inventory" recessions since much of the adjustment in total spendiug is reflected in the rate of inventory accumulation. The $1969-70$ recession differed in the respect that inventories did not fall as they did in previous recessions. Accordingly, it should not have been expected that inventories would have increased significantly in the early recovery, and they did not. The change in real (price-deflated) inventories averaged $\$ 2.3$ billion in the
} 
table

Recent Recession and Eally Recovery Perlods (Annud Rotes of Change)

\begin{tabular}{|c|c|c|c|c|}
\hline & Proustrol & prodols & crayollo, & Geflotor \\
\hline \multicolumn{5}{|l|}{ RECESSION } \\
\hline $11 / 53-11 / 54$ & $7,6 \%$ & $416 \%$ & $32 \%$ & $14 \%$ \\
\hline $11 / 5 / 711 / 58$ & 14.5 & 4.6 & $\checkmark 5.0$ & 23 \\
\hline $11 / 601 / 61$ & 7,3 & -19 & 2.4 & 16 \\
\hline N/69.1V/70 & 6.3 & 4,3 & 410 & 57 \\
\hline \multicolumn{5}{|l|}{ Recovent } \\
\hline $11 / 54411 / 55$ & 147 & 8.6 & 47 & 16 \\
\hline $11,58,159$ & 202 & 8.9 & 4,5 & $1 \%$ \\
\hline $1,61,1 / 6$ & 151 & 61 & 26 & 180 \\
\hline $1 \mathrm{~V} / 70 \mathrm{NV} / 7 \mathrm{I}$ & 38 & 5.0 & 13 & 3.3 \\
\hline \multicolumn{5}{|l|}{ TOH 4 PROO } \\
\hline $411 / 53111 / 55$ & 2.9 & 3.4 & $07 \%$ & 16 \\
\hline $111 / 57 / 150$ & 14 & 20 & 0.4 & 21 \\
\hline $11 / 60 \mathrm{~N} / 61$ & 83 & 3.0 & 0.1 & 1.3 \\
\hline v/ $69,4 / 71$ & -1.6 & 18 & 0.1 & 4,5 \\
\hline
\end{tabular}

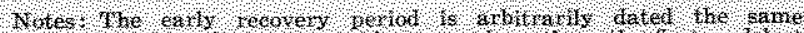

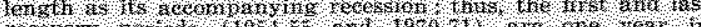

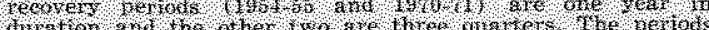
artar Natecter $\mathrm{B}$.

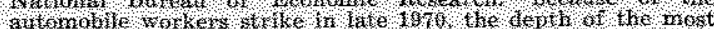

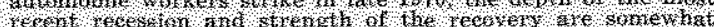

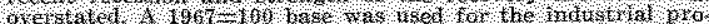

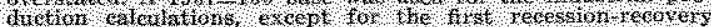
heriod, in which a 19 ar $-5=106$ lase wat used

Production and Employment-Industrial production rose about 20 percent in the first year following the 1957-58 recession, compared with a 3.4 percent increase in the year following the 1969-70 recession. However, industrial production fell at a 14.5 percent annual rate during the $1957-58$ recession, compared with a 6.3 percent decline in the $1969-70$ recession. Table I indicates that there has been a strong relation between the severity of a recession and the strength of the immediate recovery. In general, the most severe recession of the four compared was that which occurred in 195i-58, and the strongest immediate recovery followed the 1957-58 recession. The mildest recession was the most recent one (1969-70), and the mildest recovery was in the $1970-71$ period.

$1969-70$ recession, compared with an average decline for the three previous recessions of $\$ 2.9$ billion. The change in real inventories averaged $\$ 2$ billion in the $1970-71$ recovery, compared with a $\$ 3.8$ billion average for the three previous recoveries.

Some analysts have sugfested the current "low" inventory/sales ratio indicates large increases in inventories in the near future. The inventory/sales ratio is currently "low" only in relation to the past four years. It is not far from the average in relation to past early recovery periods. The averafe of the inventory/sales ratio in the early recovery period (through Novenber 1971) following the $1969-70$ recession was 1.56 compared with $1.54,1.56$ and 1.50 for the recoveries immediately following the recessions of 1960-61, 1957.58 and $1953-54$, respectively.

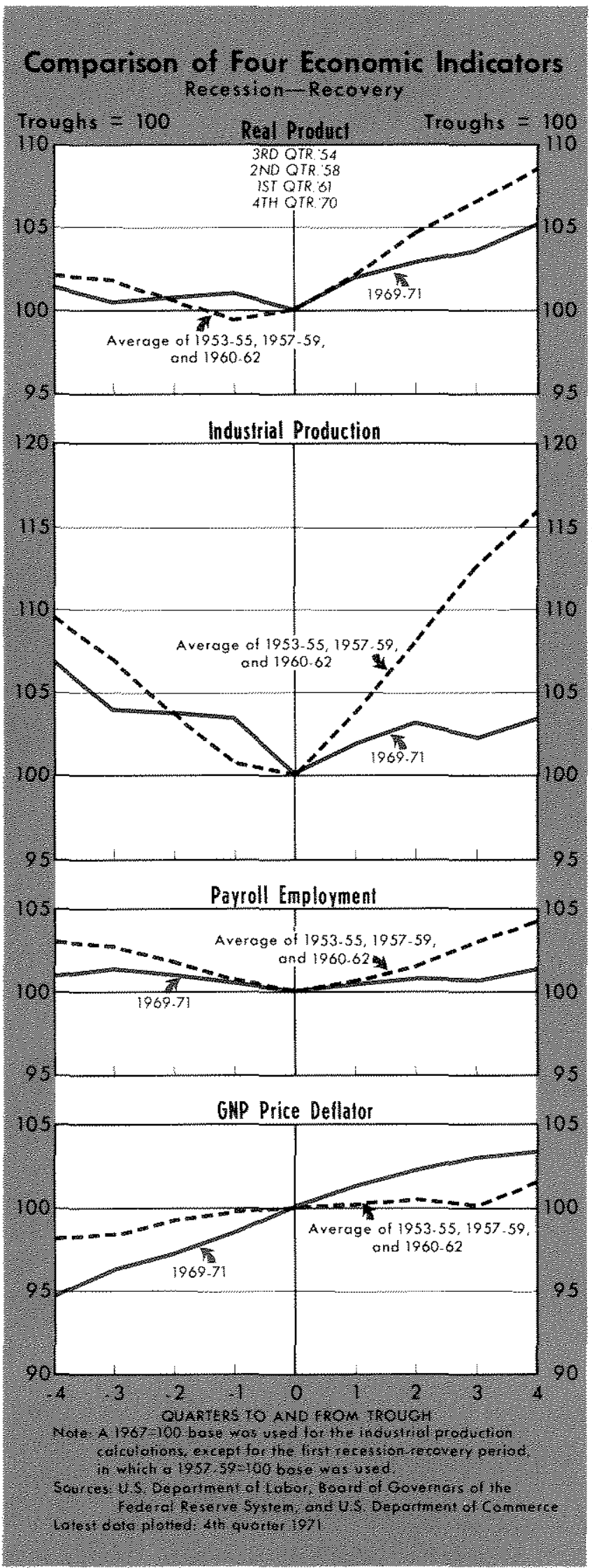


Growth in real product or industrial production has not been as strong in the 1969-71 recession-recovery period as in earlier comparable periods, but differences (particularly with the 1957-59 period) are not as great as one might expect. Although industrial production has not yet reached its 1969 peak, real product gains over the latest recession-recovery period are only slightly less than in the earlier comparable periods.

Payroll employment changes over the several periods are quite comparable. Payroll employment rose at a 0.1 percent annual rate in the 1969-71 period, compared with a 0.1 percent rate rise in the 1960-61 period, a 0.7 percent rate rise in the $1953-55$ period, and a 0.4 percent rate decline in the 1957-59 period.

Prices-One of the most substantial differences among the indicators and periods given in Table I is the movement of prices in the most recent period. The implicit GNP deflator rose in the $1969-71$ period at a 4.5 percent annual rate, more than twice as rapid as in any earlier comparable recession-recovery period. On its face, such a difference would appear to reflect substantial structural changes in the economy.

An alternative, or supplementary, explanation for the difficulty in restraining price advances in the most recent recession-recovery period is framed in terms of price anticipations. The longer that prices are permitted to rise unchecked, the more expectations of rising prices are incorporated into current prices through higher wages, rents, and other contractural obligations. Anticipations of higher prices built up over a period of years can effectively impede the efforts of stabilization authorities to halt inflation without any significant changes in economic structure (for example, more monopoly power on the part of unions or businesses) having occurred.

Prices rose for 35 quarters from the trough of the 1961 recession to the peak of the recovery ending in 1969. The next longest period from trough to peak (in the past two decades) in which prices were permitted to rise was the 15 quarter period preceding the 1953-54 recession. Given the length of the period over which prices rose and the fact that price in creases accelerated in each succeeding year after 1962 (especially in the latter half of the 1960s), it should not have been surprising that the moderate stabilization measures adopted in 1969 to stem inflation were not immediately successful in reversing the trend. ${ }^{3}$

\footnotetext{
The model of the Federal Reserve Bank of St. Lous, published in the April 1970 issue of this Review, indicated at that time that following a course of 6 percent money growth

(and highmemployment expenditures as extimated by this

Bank) from the fourth quarter of 1969 to the fourth quarter
}

\section{Structural Influences}

There are sufficient differences in the economic indicators over the recession-recovery periods to suggest that cyclical influences alone cannot explain the variations. The structural changes which have occurred over the years have affected, in particular, the short-run unemployment-prices relation.

The unemployment rate rise from 3.6 percent at the beginning of the recession to 6 percent at the end of the early recovery over the latest recession-recovery period is the most severe of the past four such periods, despite the fact that payroll employment increased more rapidly in the most recent period than in 1957-59, as rapidly as in 1960-61, and only slightly less rapidly than in 1953-55. ${ }^{4}$ Part of the explanation for this apparent paradox is that (1) the labor force has been increasing more rapidly in the past recession-recovery period than in most earlier ones, and (2) the composition of the labor force has been shifting such that proportionately mote of the labor force is composed of individuals with a historically high average rate of unemployment. Women and teen-agers, for example, comprise relatively more of the labor force than in earlier recession-recovery periods.

The change in the composition of the labor force over the past decade represents a structural shift in the economy. It is a shift which has worsened the tenuous, short-term relation between unemployment and prices through the aggravation of unemployment.

of $197 \mathrm{I}$ would find prices still rising at a rapid rate at the end of 1971 .

By late 1971 , total spending would be increasing at an eight percent rate with such monetary actions $[6$ percent annual rate of increase of money]. The rate of price increase would fall somewhat, however, because of past restrictive monetary actions. But the gain in price performance would be small, because by late 1971 prices would still be inereasing at a four percent rate [Leonall C. Andersen and Keith M. Carlson, "A Monetarist Model for Economic Stabilization," this Review (April 1970), p. 20].

A simulation of the model over the IV/1969-II/1971 period (before price and wage controls) with actual money and high-employment expenditures and coefficients estimated through IV/1969, projected a 4.9 percent six-quarter average price increase, compared with an actual average of 5.4 percent. See Keith M. Carlson, "Projecting With the St. Lotis Model: A Progress Report," this issue of the Review, pp. 20-27, for other conments on the model's predictive performance.

tThe rise in the unemployment rate from 3.6 percent in IV/1969 to 6 percent in IV/1971 reflects the persistence of relatively high levels of tinemployment during the recent recovery. Unemployment rose from 2.7 percent of the labor force in III/1953 to 4.1 percent in $111 / 1955$, an increase of 1.4 percentage points. Unemployment increased 1.6 percentage points from 4.2 percent to 5.8 percent in the $1957-59$ period and one percentage point from 5.2 to 6.2 percent in the $1960-61$ recession-recovery period. 


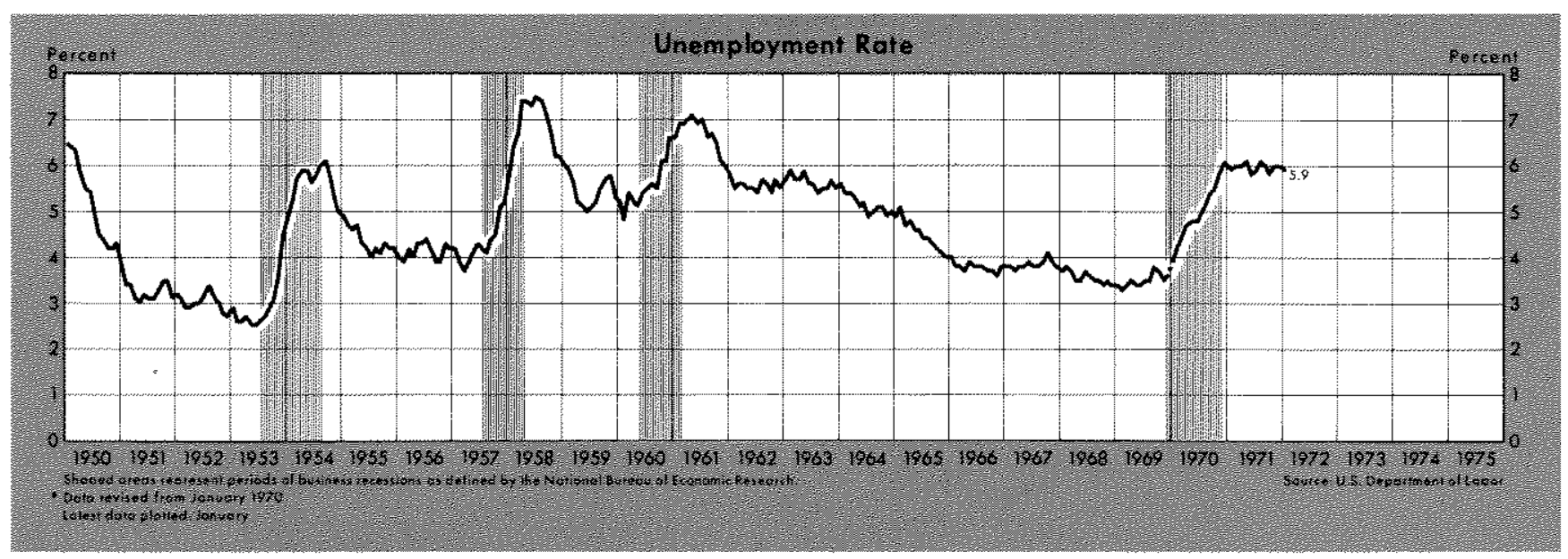

Another structural change which may have affected unemployment is the fact that U.S. exports relative to imports have been slowing in recent years. Net U.S. exports slowed each year (except 1970) from $\$ 8.5$ billion in 1964 to $\$ 0.7$ billion in 1971 . Employment and output in a number of U.S. industries are probably less than they would be otherwise if it were not for the deterioration of the U.S. competitive position over the past several years. Over a long period, U.S. resources may shift from industries with declining export demand to other industries, but during the period of adjustment, employment is probably affected adversely.

Quite likely, structural changes have also hampered efforts to slow price increases. The shifting composition of final output from the production of goods to the production of services has probably tended to reinforce price pressures. Because of the nature of many services rendered, such as those of barbers, lawyers, and government workers, productivity gains are difficult to achieve (or measure). The production of goods such as automobiles or appliances can be more easily enhanced by technological advances and/or mass assemblage techniques. Lower productivity, other things equal, results in lower potential output, a more severe total supply constraint relative to total demand, and consequently, higher prices."

The minimum wage, which puts a floor under wage rates, and also tends to increase unemployment by making inexperienced workers ineligible for many jobs, has been extended to cover more workers in recent years than in the 1950s. Although the minimum wage was designed to benefit the worker, it is possible

\footnotetext{
5See Roger W. Spencer, "Population, The Labor Force, and Potential Output: Implications for the St. Louis Model, this Review (February 1971), pp. 15-23.
}

that it has affected adversely both unemployment and prices. This structural shift is one endorsed by law.

Because structural changes probably have accounted for some worsening of the prices-unemployment relation, structural measures could play a strong role in improving the relation. Job training, information and relocation subsidies, and the elimination of legal and institutional barriers to jobs (such as the minimum wage) could bolster orthodox monetary and fiscal stabilization techniques to achieve the goals of a low rate of unemployment and price stability.

\section{Stabilization Policy Actions}

The impact of monetary and fiscal policy actions on economic activity is, like cyclical and structural influences, not easy to identify or measure. A rough approximation of aggregate monetary and fiscal policy actions prior to and during recent recession-recovery periods is given in Table II. Such actions normally influence economic activity with some lag, and a period of three quarters before each peak was arbitrarily selected as the point from which actions affecting activity over the course of the recessionearly recovery periods should be dated. ${ }^{6}$ Money, defined to include demand deposits and currency in the hands of the public, is used to represent monetary policy actions and high-employment expenditures is selected as the fiscal policy variable. Both are deflated by the implicit price deflator to account for varying price trends over the past twenty years. ${ }^{7}$

\footnotetext{
"See Andersen and Carson, "A Monetarist Model," for some evidence on the relevant length of policy action lags.

'Another method of adjusting stabilization policy actions for changes in trend over a long period is given in Leonall $\mathrm{C}$. Andersen, "A Monetarist View of Demand Management: The United States Experience" this Review (September 1971), p. 9. Andersen adjusts the money supply by comparing its growth relative to various trends over the $1952-71$ period.
} 


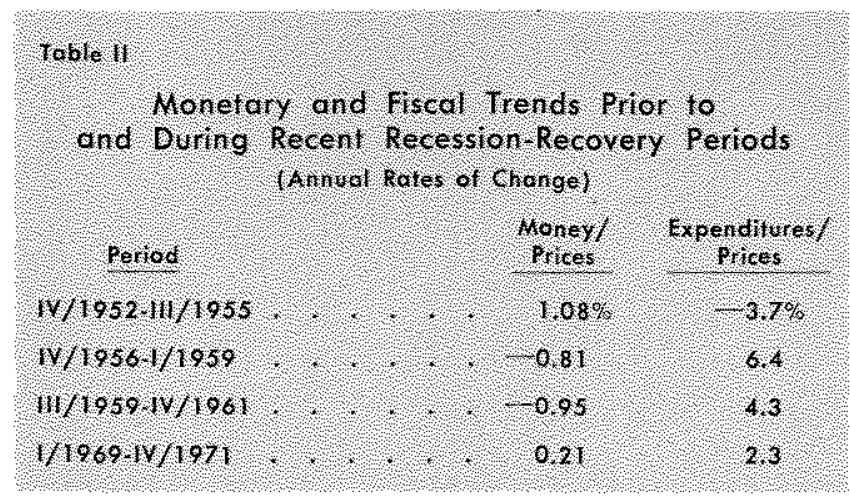

Rapid growth of the money stock, relative to prices, is presumed to have a short-run stimulative effect on the economy, as is rapid growth of high-employment expenditures relative to prices. For example, there would probably be general agreement that monetary actions were stimulative in the IV/1967-IV/1968 period when money/prices rose 3.2 percent and restrictive in the IV/1968-IV/1969 period when money/prices declined 1.3 percent. $^{8}$

Table II suggests that monetary actions were relatively stimulative in the $1952-55$ period, but fiscal actions were not (unwinding of the Korean War). Fiscal actions were relatively stimulative in the $1956-59$ and 1959-61 periods (compared to the 1952-55 and 1969. 71 periods), but monetary actions were not. Neither monetary nor fiscal actions were overly expansive in the $1969-71$ period.

By these crude indexes, the slightly stimulative monetary actions in 1969-71 relative to $1956-59$ or 1959-61, would tend to exert more inflationary pressure than in the two earlier periods, and also tend to maintain the unemployment rate at a relatively lower level than in the two earlier periods. This most recent monetary trend may represent a partial explanation for the lack of success in slowing price rises in recent years relative to the two earlier periods, and for the success attained in holding the aggregate unemployment rate lower than in the two earlier periods (the unemployment rate reached a peak of 6 percent in the latest recession-recovery period, compared with 7.4 percent and 7 percent for the 1957-59 and 1960-61 periods, respectively).

Two other factors - the shifts in composition of the labor force mentioned above and the sizable defense cutbacks in recent years (reflected in the 2.3 percent figure for expenditures/prices in the table) - have contributed to the high unemployment rates for in-

It should be noted that monetary and fiscal atthorities cannot control money/prices and expenditures/prices over any brief period; they nay, however, control money and expenditıres.

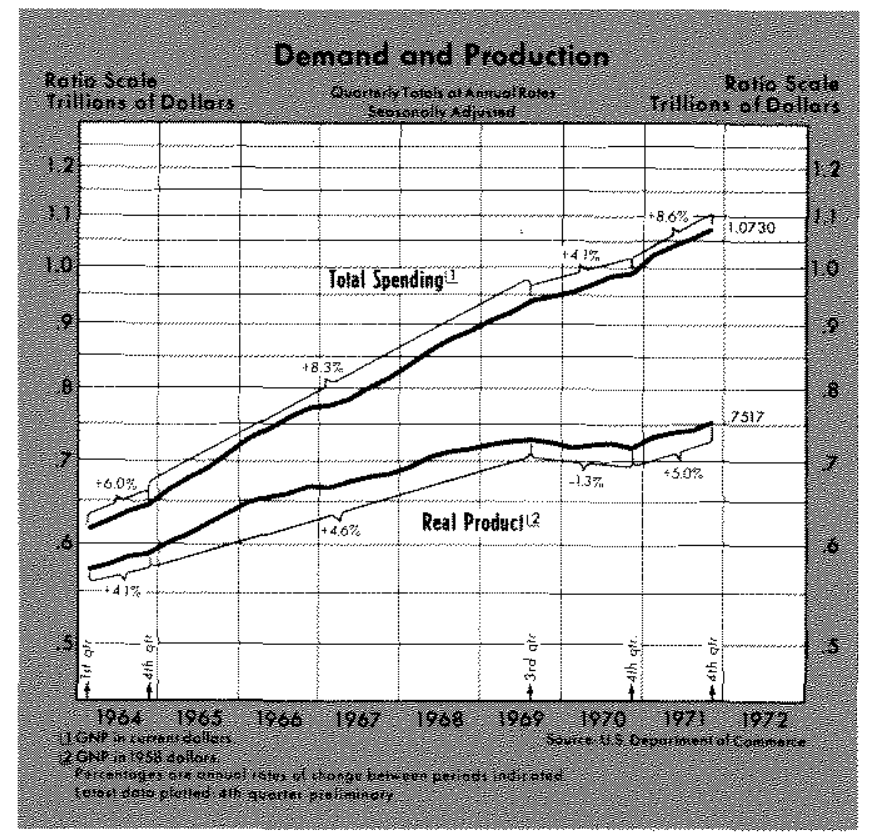

experienced workers across the country and defenseoriented workers in particular geographic areas of the United States. ${ }^{9}$

\section{The Economic Outlook}

The current economic outlook is based on recent and projected cyclical, structural and policy influences. These factors affect economic activity in 1972 and beyond.

\section{Current Cuclical and Structural Considerations}

The U.S. economy begins the year 1972 at a position on the business cycle not substantially dif. ferent from that a year ago in terms of actual "momentum" relative to potential. Although real product rose at a 6.1 percent rate from the third to the fourth quarter of 1971 , after increasing at a 3 percent rate from the first to the third quarter, output advances have not been sufficient to reduce unemployment. The rate of utilization of both labor and capital resources has changed little in the past year. Actual output is approximately 93 percent of potential output, about the same as a year ago. Thus the "momentum" of the economy moving into 1972 gives little reason by itself to alter economic projections from the actual developments of 1971.

"The total employment attributable to military expenditures, including military forces and government civilian personnel, dropped from a peak of 7.8 million in 1968 to about 6.1 million in 1971 , a loss of 1.7 million jobs over the three-year period, with more than 900,000 of these lost during 1970-71." Richard P. Otiver, "Employment Effects of Rediced Defensed Spending," Monthly Labor Review (December 1971), p. 4 . 
Most structural changes occur slowly over time, but there are some important developments changing the 1972 outlook from that of 1971. Little is currently known as to whether preferences for liquidity and saving relative to the purchase of goods and services have changed much from last year, but it is unlikely that the long-term trend of preference toward services from goods will be much altered. Moreover, there is little basis on which to project changes in economic activity in 1972 over 1971 because of differing resource trends, weather changes, war developments, technological advancements, or strike patterns.

There are at least two structural changes which will likely exert some influence on the economy in 1972. First, the anticipated improvement in demand for U.S. exports relative to imports should have an expansionary effect on total spending, output, and employment. ${ }^{10}$ Second, price and wage controls should contribute to a slowing in the rate of increase of prices in 1972, given moderate stabilization actions.

Price increases leveled off in 1970 and 1971, and may have been decelerating slightly when the Presi. dent called for a wage-price freeze last August 15. Since the imposition of the freeze and the second phase of the Administration's program, measured prices have slowed. Wholesale prices of industrial commodities increased at a 0.5 percent rate from August to December, after rising at a 4.6 percent rate in the preceding eight months. Consumer price increases slowed to a 2.5 percent rate from August to December, compared with a 3.8 percent rate from December 1970 to August.

Problems of administration and equity will likely intensify the longer the program remains in existence, but in the latter months of 1971 , at least, wage and price controls seemed to have had the desired effect. The potential for eventual success of the program is enhanced by: (1) the fact that the controls have not been accompanied by excessive monetary stimulus; (2) the fact that there is currently substantial economic slack; (3) the possibility that controls may have helped stem anticipations of higher prices; and

$10^{4}$ The expected employment gains for the United States will probably be spread over about two years, too, according to Peter G. Peterson, the White House International Economic Policy Chief. Each $\$ 1$ billion of payments tarnabout will create 60,000 to 80,000 jols, he estimates. Thus, attaining the Connally goal of a $\$ 9$ billion swing for the better could mean more than 700,000 additional jobs by late 1973 ; that in itself would be enough to lower the unemployment rate to about 5.2 percent from November's 6 percent" Richard F. Janssen, "The New Dollar: Devaluation of 8.57 Percent Likely to Create Jobs, Help Nixon Summitry," The Wall Street Joumal, December 20,1971 , p. 25 . These exportrelated employment gains anticipated by the administration seem overly optimistic.

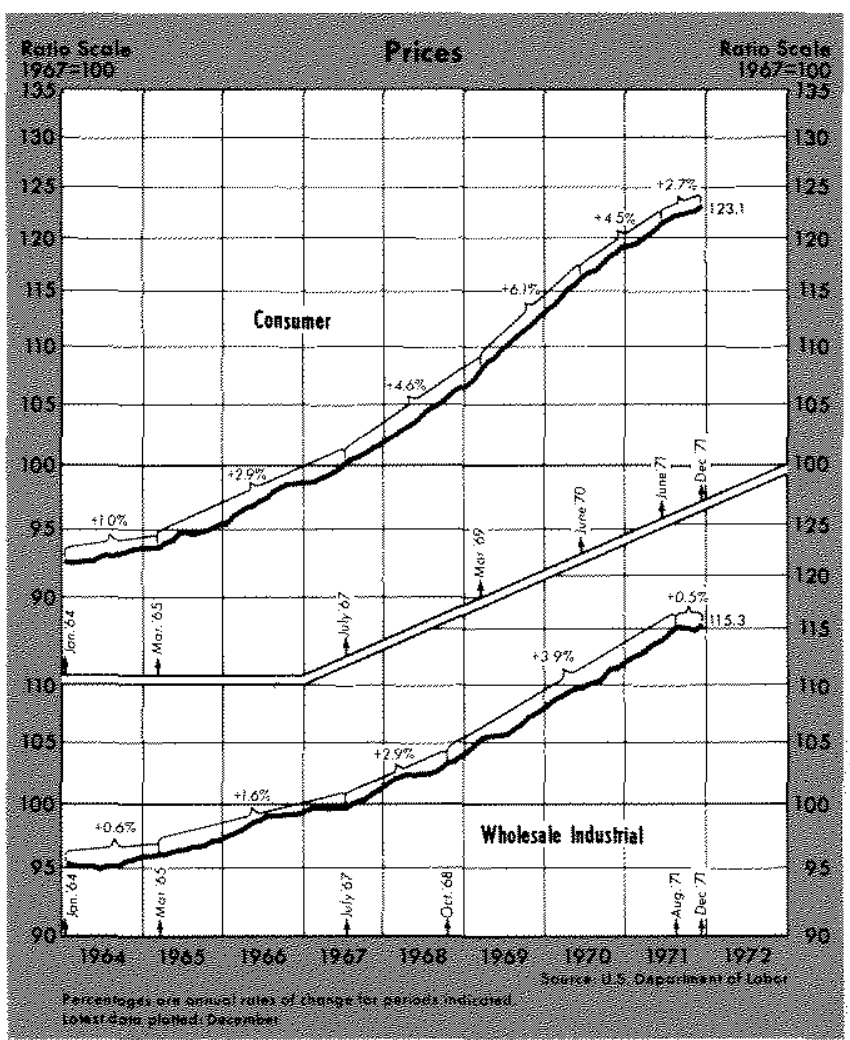

(4) the fact that the wage negotiation calendar for 1972 is relatively light.

\section{Recent Monetary and riscal Policy Actions}

The course of economic activity in 1972 depends, in part, on both monetary and fiscal policy actions. There is a carry-over effect from actions taken last year, and there will be some effect from actions taken during 1972 .

Monetary Actions - The rate of growth of the money stock fluctuated more widely in 1971 than usual. After rising 5.4 percent from December 1969 to December 1970 , the money stock accelerated to a 10.3 percent annual rate of growth in the first seven months of 1971 , and then slowed markedly to very little growth during the last five months of the year and into January 1972.

These violent swings in money movements were accompanied by roughly similar changes in interest rates. The three-month Treasury bill rate, for example, rose from a low of 3.3 percent in March 1971 to a peak of 5.5 percent in July, and then fell to a little over 3 percent in January 1972. Falling interest rates in the latter half of 1971 have been viewed by many analysts as a spur to economic activity in 1972, and indeed a lower cost of capital is often one of the ways by which monetary changes influence spending. 


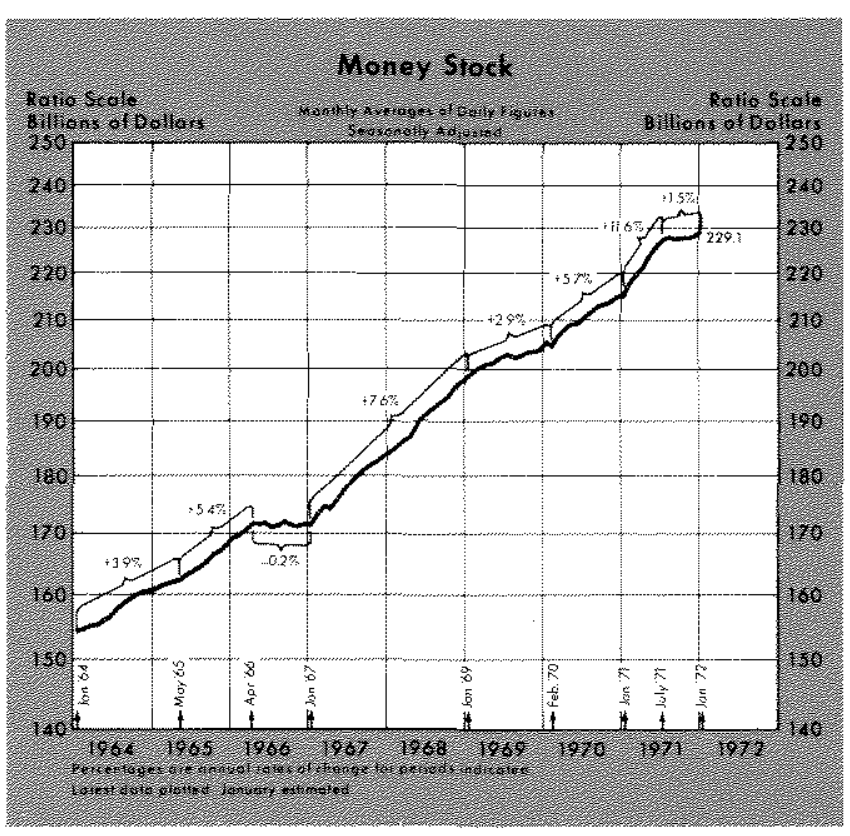

However, because there are channels other than interest rates through which monetary growth affects economic activity, the recent slower growth in the money stock may have a restrictive effect on spending (assuming a relatively stable demand for money). When the money stock expands rapidly relative to demand, its value falls, and people exchange money for goods and services at a rapid rate. Conversely, when growth of the money stock slows, relative to demand, its higher value makes people more reluctant to exchange their cash for goods and services. Persistent and pronounced swings in monetary growth rates have consistently led similar swings in spending.

Thus, the slower monetary expansion during late 1971 may retard economic activity during the first part of 1972 from what it would otherwise have been. Activity later in the year will be influenced by monetary expansion during the early part of 1972 .

Fiscal Actions - Federal expenditures affect economic activity in two ways. First, Federal Government outlays, whether financed by taxes or borrowed from the public, have an important short-run stimulative effect on total spending. Over longer periods of time, such expenditures tend to displace private purchases of goods and services. Second, increased Federal Government expenditures, financed in part by borrowing, often induce expansion in the money stock, as the Federal Reserve "monetizes" a part of the debt increase. Tax reductions also tend to expand the size of the deficit. The larger the deficit, the more likely is the Federal Reserve to increase its purchases of Trensury securities, which in turn, increases the money stock.

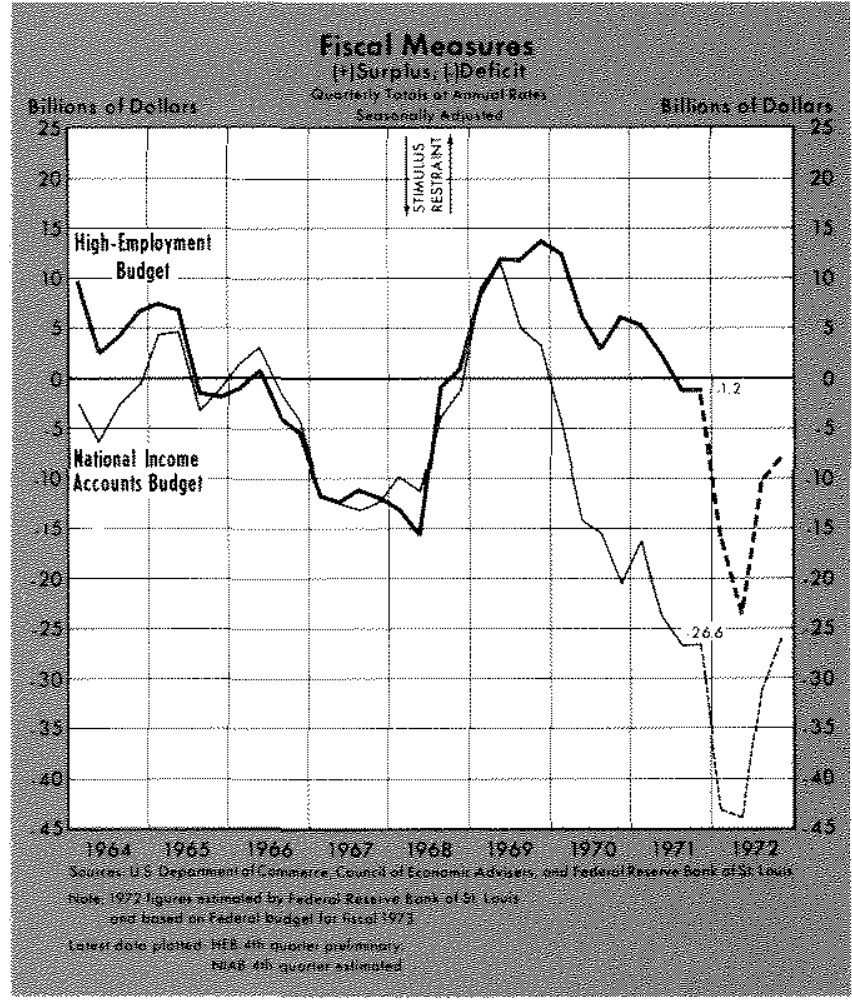

The Federal budget deficit in fiscal year 1971 (on a unified budget basis) was $\$ 23$ billion, the second largest deficit recorded since World War II. The budget deficit for fiscal year 1972, estimated at $\$ 11.6$ billion in early 1971, has been revised upward to $\$ 38.8$ billion. Reasons for the revision include an overestimate of the strength of the economy in calendar year 1971, and the Administration's new fiscal pro. posals of last August and this January. Congress has already acted favorably on a number of the Administration's proposals of August 1971.

The high-employment budget, which assumes budget expenditures and tax revenues at a constant 4 percent level of unemployment, is expected to shift markedly from a $\$ 4.2$ billion surplus (as estimated by this Bank) in fiscal $197 \mathrm{I}$ to a $\$ 10.5$ billion deficit in fiscal 1972. The fiscal 1973 high-employment budget is expected to run a $\$ 10.9$ billion deficit. Thus the budget, by such actions as the 7 percent tax investment credit, the increased personal income tax exemptions and accelerated expenditures, should have a stimulative effect on economic activity this calendar year.

\section{Proiections}

Stimulative fiscal actions provide much of the basis for the very optimistic 1972 forecasts which have appeared regularly in the media the past few months. 
A large majority of economic forecasters have predicted a strong surge in spending this year. Such unanimity is difficult to understand in view of the additional uncertainties with which the analysts are faced in 1972. The chief unknown influences on spending are usually monetary and fiscal actions, but this year the analysts must also project the expected impact of the possible removal of some trade barriers, the dollar devaluation, and foreign exchange rate adjustments, as well as the effects of price-wage controls, their duration, and the successive phases, if any, of controls. Uncertainty often breeds divergence, but this year the product of uncertainty is conformity.

The standard projections of economic activity in 1972 include: (1) approximately a $\$ 100$ billion rise in total spending compared to a $\$ 73$ billion increase in 1971; (2) an increase in real product growth from 2.7 percent in 1971 to about 6 percent; (3) a decline in the rate of price increase from 4.7 percent in 1971 to a little over 3 percent; and (4) a steady fall in the unemployment rate from 6 percent to a little over 5 percent by year end.

Most forecasters believe these ebullient figures will be achieved by way of the following standard route: the consumer, bolstered by the progress of the wage price control program and higher tax exemptions, starts spending more (and saving less); the increased expenditures reduce sellers' inventories, which must then be replenished; a greater sales volume leads to higher profits which, together with the tax investment credit, induce capital expenditures; exports accelerate in response to increased demand from abroad, thereby creating many more jobs; residential construction and state and local spending pick up moderately, while Federal Government purchases of goods and services accelerate.

MIT-PENN-SSRC Model-Typical of the models which generate such projections for 1972 is the MIT. PENN-SSRC(MPS) econometric model. It is a large model of the economy with many behavioral relationships and most of the latest features in model building, such as a well-developed financial sector. In addition, the model can give detailed projections of each economic sector in response to any of a large number of simulated policy actions. It, like most large models, incorporates cyclical forces, some structural changes, and possible policy alternatives.

Unlike the small St. Louis Bank model, the Jarger, more detailed MPS model: (1) contains both money demand and supply functions; (2) can account to some extent for the expected improvement in U.S. net exports; (3) can simulate changes in activity

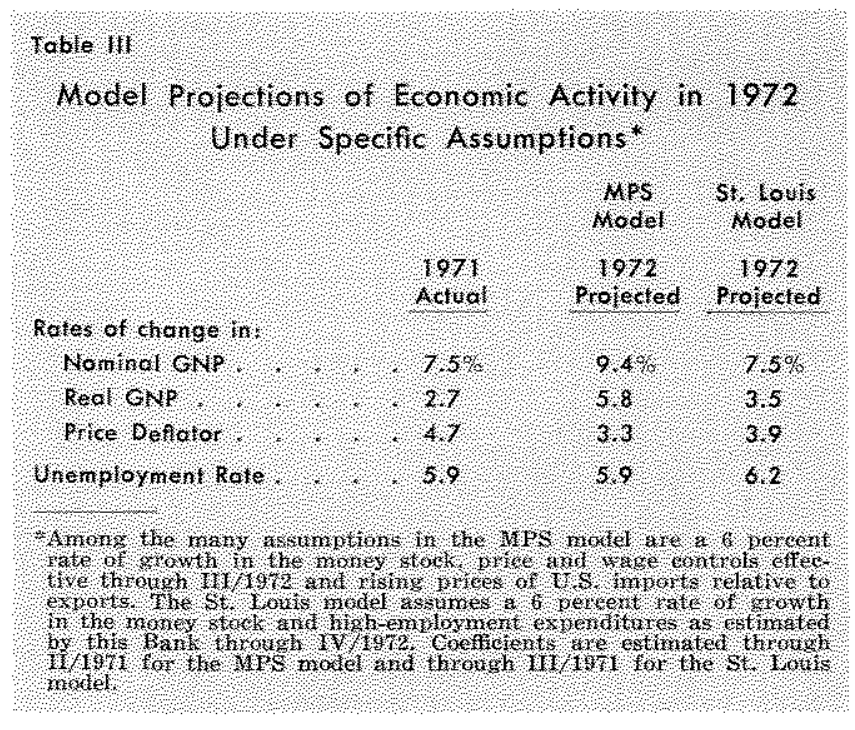

under varying assumptions of both price and wage constraints; (4) has relatively long lags in the effect of changes in the money supply on economic activity and short lags in the effect of fiscal actions on economic activity; (5) projects estimates of total spending indirectly by the addition of GNP components rather than directly.

Table III indicates that the MPS model, under the assumptions that the money stock will grow at a 6 percent rate, that price and wage controls will be effective through III $/ 1972$, and that import prices will rise relative to the prices of U.S. exports, projects changes in total spending, real output, and prices in 1972 similar to those of the "standard" forecast. ${ }^{11}$ The unemployment rate projection is high relative to the standard.

St. Louis Model-Table III gives the projections of the St. Louis model for total spending, real output, prices, and the unemployment rate using the 6 percent money growth assumption employed with the MPS model. In this model, monetary and fiscal actions affect prices and real output (and, in turn, employment) by influencing the course of total spending. Monetary actions are the dominant source of changes in total spending. Whether the spending is channeled into real output changes or price changes depends on the degree of slack (actual output relative to potential) in the economy and the intensity of price anticipations. The model can account for cyclical forces, but offers a more limited selection of policy alternatives than the large models. Some provision for structural change is found in the potential output variable.

${ }^{11}$ Six percent money supply growth was arbitrarly selected as the monetary assumption. Other assmptions are sinxilarly arbitrary. 
The St. Louis model projects considerably smaller economic advances in 1972 over the year 1971 than either the standard or the MPS forecast (based on a 6 percent money growth assumption). Total spending, according to the St. Louis model, will rise 7.5 percent, the same as in 1971 , real output will increase 3.5 percent, somewhat more than in 1971 , prices will rise 3.9 percent, somewhat less than in 1971, and the unemployment rate will be little changed from this past year.

There are three basic reasons why this set of St. Louis projections differs so much from the standard. First, the model has incorporated the sharply lower growth of the money stock in late 1971, the effect of which does not appear in the MPS or most other models for a long period. Second, no provision is made for the actions of the Price Commission and Pay Board. Third, the model does not account for the expected increase in foreign demand for U.S. goods.

Because price and wage controls will likely keep price advances in 1972 below what they otherwise would be, and because increased demand for exports will probably stimulate spending, output and employment, the St. Louis projections for prices and unemployment should be adjusted downward, and the projections for total spending and real output upward, given a 6 percent rate of increase in the money stock. These projections should not be adjusted to the optimistic levels of the standard forecast, however, since the standard forecast is not appropriately "adjusted" for the influence of the recent slowdown in the growth rate of money.

\section{Looking Past 1972}

To this point, only a limited set of figures for a few economic variables for a single year, 1972, have been discussed. To focus on such a narrow field is to miss much of the importance of current and future domestic economic developments. At least one issue price and wage controls - merits further consideration. The adoption of price and wage controls by the U.S. Government in a period of peace time is a move which has strong long-term implications for our basically free market economy. Although there have been some brief periods of success with controls in this country as well as in a number of foreign countries, instances in which inflation was effectively curbed over sustained periods are rare indeed. Price and wage freezes have typically been followed by controls inequitably applied and ineffectively administered.

The initial cuphoria over the fact that someone is doing something to stop inflation has often given way to dissatisfaction on the part of those whose incomes do not rise as fast as others and to cheating by those who cannot buy or sell goods at the administered prices. Once the controls are removed, past experience indicates prices may rise back to about where they would have been in the absence of controls. ${ }^{12}$

The MPS model, using the assumed 6 percent rate of monetary growth, indicates that prices would rise about as rapidly in 1973 as in 1972 if controls were removed toward the end of this year. This model also indicates that without any controls, but with moderate monetary growth, there would be less inflation in 1973 than in 1972, a result also given by the St. Louis model.

\section{Summary}

Nineteen seventy-one was a year of moderate recovery following the moderate recession in 1970. Comparisons with previous recession-early recovery years indicate that economic expansion in the 1970-71 period was slightly weaker than in earlier comparable periods. A major difference is that prices rose at a much faster rate during the recent period than in the earlier ones. Some structural changes in the economy have undoubtedly occurred over the years, but they have probably played a minor role in influencing recent activity relative to normal cyclical adjustments and policy changes. Excessively stimulative monetary and fiscal policies over the extended $1965-68$ period, for example, undoubtedly made the recent inflationary situation much more difficult to control than earlier ones.

Most projections of economic activity in 1972 are quite optimistic relative to the actual experience of 1971. What makes 1972 that much different from 1971? The differences may be explored by examining cyclical influences, structural changes, and policy actions.

The economy begins 1972 at only a slightly different position on the business cycle than a year ago in terms of actual "momentum" relative to potential. The

\footnotetext{
12Lloyd Ulmar and Robert Flanagan recently completed a study of incomes policies in other countries. "However, as indicated at the ontset, periods of apparent effectiveness Iof price-wage controls were typically short-lived; they were frequently followed by wage or price explosions which sometmes blew up the policies themselves. Thus the policy at best seems to have been gaited for a short sprint rather thane a long race, which suggests that it was better suited to deal with short-run emergencies like balance-of-payments disequilibria than with persistent inflationary forces." See loyd Ulman and Robert f. Flanagan, Wage Restraint: A Study of Income Policies in Western Eutope (Berkeley and Los Angeles: University of California Press, 1971) p. 223.
} 
rate of utilization of both labor and capital resources is little changed from this time last year. Actual output relative to potential output is approximately the same as a year ago. Some structural aspects of the economy such as the composition of the labor force and the ratio of goods to services will be little different than in 1971. Productivity may rise at a more rapid rate in 1972 than 1971 , but short-run changes in productivity are more a result of cyclical changes than a cause.

There are at least two institutional changes which will likely exert a strong influence on the economy in 1972. First, the anticipated improvement in demand for U.S. exports relative to imports due to exchange rate and tariff changes should have an expansionary effect on total spending, output and employment. Second, price and wage controls should contribute to a slowing in the rate of increase of prices in 1972 . If the controls are effective over the short period of a year, many analysts believe this will have a positive influence on consumer confidence and lead to spending gains. The effect of controls on profits, work stoppages and price-wage escalator contracts is unclear.
A major difference between 1971 and 1972 is that fiscal policy actions will likely be much more stimulative. To the extent that the large, projected 1972 deficit is "monetized" by the Federal Reserve System, monetary policy may also be quite stimulative. Most economic analysts and models have not, however, accounted for the recent slowing in the rate of growth of the money stock. Correction for this factor suggests somewhat lower projections than the norm for spending, output, and employment in 1972.

Focusing on economic developments in 1972 runs the risk of overlooking the important longrange implications of recent policy actions. The record of pricewage controls and sharp fluctuations in the money stock over a number of years gives little reason for continuation of such actions over an extended period. In developing stabilization policies, it should be recognized that an economy the magnitude of ours cannot be steered in any direction instantaneously, and that effective policies should look to the long-run effects, rather than to the short cures which often lead to long-run instability.

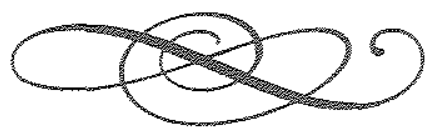

